\title{
The Influence of Motivations and Discipline Employee Performance at PMB Trisakti School of Tourism Jakarta
}

\author{
Johannes Kurniawan $^{1}$, Doni Muhardiansyah ${ }^{2}$ and Nurbaeti $^{3}$ \\ ${ }^{1}$ Bunda Mulia University, Jakarta, Indonesia \\ ${ }^{23}$ Sekolah Tinggi Pariwisata Trisakti, Jakarta, Indonesia
}

Email: ${ }^{1}$ jkurniawan@ bundamulia.ac.id, ${ }^{2}$ doni.muhardiyansyah@ stptrisakti.ac.id and ${ }^{3}$ nurbaeti@ stptrisakti.ac.id

\begin{abstract}
The purpose of this study was to analyze the motivation and discipline on employee performance at PMB Trisakti School of Tourism as well as to analyze dominant factors that influence the employee performance. In this study, researchers conducted a study on the employees that work at PMB Trisakti School of Tourism to find out the relationship and influence of the motivation and discipline on employee performance. The method used is descriptive research method is method to analyze and explain the data to what it is. The collection of data by distributing questionnaires as much as 40 respondents with random sampling technique by using a calculation slovin. While the method of analysis using the correlation coefficient formula and simple regression analysis was analyzed and drawn a hypothesis in which hypothesis are confirmed. From the result of this study concluded that there is a relationship and influence of the discipline variable trough to the employee performance of PMB Trisakti School of Tourism. The dominant factors that influence the employee performance from discipline variable is attitude factors.
\end{abstract}

Keywords-motivations, disciplines, employee performances, SPSS, PMB STP Trisakti

\section{INTRODUCTION}

The survival of a company depends heavily on the productivity, effectiveness and efficiency of its workforce. The existence of manpower in carrying out its activities must be supported by facilities and infrastructure and good management in accordance with the expectations of the company without any sense of doubt and disappointment. Workers within a company are an important resource in supporting business fluency. The success of the company in achieving its objectives, which is determined by the human resources that exist within the company in performing their duties according to their respective fields-each. Human resources that are the main resources must be processed by management in order to perform their duties properly in accordance with the intended purpose. Trisakti School of Tourism which is engaged in hospitality management education, requires good human resources to run its operations. Without good human resource management the company will not be able to run well and smoothly, so it is very important for the company to take full advantage of all human resources possessed as much as possible.

The decline or improvement of worker performance is the most important element in supporting the survival of the company especially in Trisakti School of Tourism, the human element is the most important because most of the work process is done by humans. So that the need for work motivation that can support and provide continuous support for workers to have high performance and will be able to do the job very well.

Trisakti School of Tourism is one of the universities that have enough big name. Having a vision of "Becoming a Higher Education of Global Quality Tourism and Center of Excellence (Center of Excellence) Development of Tourism Science and Hospitality". Where to achieve that vision, Trisakti School of Tourism continues to seek and form qualified candidates. So this is where Trisakti School of Tourism formed the department of Ka. Center for Cooperation \& Marketing led by Mr. Ismeth Emier O, SE., MM., Which has two units under it namely, UPT Cooperation \& Public Relations led by Dian Octarina, M.Si. Par and UPT Marketing led by Tri Djoko Sulistyo, S.Sos.

Marketing is one of the principal activities undertaken by entrepreneurs in their endeavors to sustain their survival, to grow and to earn profits. Success or failure in achieving business goals depends on the skills of entrepreneurs in the field of marketing, production, finance and other fields. It 
also depends on the ability of entrepreneurs to combine these functions so that the company's business can run smoothly.

TABLE I. PMB STP TRISAKTI 2014 - 2016

\begin{tabular}{|c|c|c|c|c|c|c|c|c|}
\hline \multirow{2}{*}{ No. } & \multirow{2}{*}{ Quality Goals } & \multirow{2}{*}{ Indicator } & \multicolumn{2}{|c|}{2014} & \multicolumn{2}{|c|}{2015} & \multicolumn{2}{|c|}{2016} \\
\hline & & & Target & Reached & Target & Reached & Target & Reached \\
\hline 1 & $\begin{array}{l}\text { Admissions New } \\
\text { DIV Hospitality }\end{array}$ & $\begin{array}{l}\text { Number of New } \\
\text { Students D IV } \\
\text { Hospitality }\end{array}$ & 300 & 369 & 300 & 369 & 300 & 405 \\
\hline 2 & $\begin{array}{l}\text { Acceptance of } \\
\text { New Students at } \\
\text { DIII Hospitality }\end{array}$ & $\begin{array}{l}\text { Number of New } \\
\text { Students D III of } \\
\text { Hospitality }\end{array}$ & 40 & 47 & 40 & 48 & 40 & 65 \\
\hline 3 & $\begin{array}{l}\text { Admissions New } \\
\text { DI Hospitality }\end{array}$ & $\begin{array}{l}\text { Number of New } \\
\text { Students DI } \\
\text { Hospitality }\end{array}$ & 40 & 49 & 40 & 47 & 40 & 43 \\
\hline 4 & $\begin{array}{l}\text { Results of the } \\
\text { New Student } \\
\text { Test DIV } \\
\text { Hospitality }\end{array}$ & $\begin{array}{l}\text { Number of new } \\
\text { students D IV } \\
\text { Hospitality with } \\
\text { PMDK grade test } \\
\text { results }\end{array}$ & 75 & 196 & 75 & 221 & 75 & 193 \\
\hline 5 & $\begin{array}{l}\text { The results of the } \\
\text { New Student } \\
\text { DIII Test Scores }\end{array}$ & $\begin{array}{l}\text { Total New } \\
\text { students D III } \\
\text { Hospitality with } \\
\text { PMDK grade test } \\
\text { results }\end{array}$ & 10 & 11 & 10 & 5 & 10 & 17 \\
\hline 6 & $\begin{array}{l}\text { The results of the } \\
\text { New Student D1 } \\
\text { Test Scores }\end{array}$ & $\begin{array}{l}\text { Total New D I } \\
\text { Hospitality } \\
\text { student with } \\
\text { PMDK grade test } \\
\text { results }\end{array}$ & 10 & 11 & 10 & 5 & 10 & 6 \\
\hline 7 & $\begin{array}{l}\text { Acceptance of } \\
\text { New Students } \\
\text { DIV of Travel } \\
\text { Business }\end{array}$ & $\begin{array}{l}\text { Number of new } \\
\text { Students D IV } \\
\text { Business Travel }\end{array}$ & 80 & 104 & 80 & 88 & 80 & 113 \\
\hline 8 & $\begin{array}{l}\text { The results of the } \\
\text { New Student } \\
\text { Test DIV of } \\
\text { Traveling Travel }\end{array}$ & $\begin{array}{l}\text { New students D } \\
\text { IV Business } \\
\text { Travel with } \\
\text { PMDK grade test } \\
\text { results }\end{array}$ & 20 & 47 & 20 & 55 & 20 & 55 \\
\hline 9 & $\begin{array}{l}\text { Admissions S-1 } \\
\text { Hospitality and } \\
\text { Tourism }\end{array}$ & $\begin{array}{l}\text { Number of new } \\
\text { students } S 1 \\
\text { Hospitality and } \\
\text { Tourism }\end{array}$ & 40 & 31 & 40 & 40 & 40 & 35 \\
\hline 10 & $\begin{array}{l}\text { Results of the } \\
\text { New Student } \\
\text { Test S-1 } \\
\text { Hospitality and } \\
\text { Tourism score }\end{array}$ & $\begin{array}{l}\text { Number of new } \\
\text { students S1 } \\
\text { Hospitality and } \\
\text { Tourism with } \\
\text { PMDK test } \\
\text { results }\end{array}$ & 10 & 19 & 10 & 18 & 10 & 8 \\
\hline
\end{tabular}

It can be seen in Table that from 2014 until 2016 PMB STP Trisakti can reach even exceeded the set target, but it can be noticed at number 5 in 2015 PMB has not succeeded to achieve according to the target set. At number 6 in 2015 and 2016 PMB has not succeeded in achieving the target set. At number 9 in 2014 and 2016 PMB has not succeeded in achieving the target set. At number 10 in the year 2016 PMB has not managed to reach the target set. This is interesting to be researched with only 
40 workers who are all students who work well so that the target of PMB in several years can be achieved or even exceeded the target set by the institution achieved. This achievement is whether motivation and work discipline affect the performance of PMB workers.

Based on the background of the above problem then the formulation of problems that can be prepared is;

1. What is the effect of motivation on the performance of PMB Trisakti School of Tourism - Jakarta?

2. How does the effect of work discipline on the performance of PMB Trisakti School of Tourism Jakarta?

3. How does the motivation and work discipline work together on the performance of PMB Trisakti School of Tourism - Jakarta?

4. What are the factors that most affect the performance of PMB Trisakti School of Tourism Jakarta?

\section{LITERATURE REVIEW}

\section{A. Motivation}

Motivation is often interpreted in terms of encouragement. Encouragement or energy is a movement of the soul and body to do. In essence, working people tend to be driven by the desire to meet their needs, as well as social activities to maintain the survival and satisfaction in himself and others. Physiological factors are factors who related to physical things or riel associated with the employees themselves such as financial factors (salary, wages, letters of appreciation and so forth), the work factor itself as well as supervision and supervisory factors. Need for affiliation is the desire to establish a friendly and intimate interpersonal relationship. Need for achievement is the urge to go beyond, reach the standards, and strive to succeed (Robbins, 2012).

\section{B. Discipline}

Discipline is a form of obedience to the rules, both written and unwritten set. Discipline must be developed to grow also order and efficiency. Attitude is the mental and employee behavior derived from the awareness or willingness of himself / herself in carrying out the duties and regulations of the company, consisting of: a. Attendance relates to the existence of employees in the workplace for work, b. Able to utilize and use the equipment well. Norm is the rules on what employees can and should not do while inside the company and as a reference in attitude consist of: a. Obeying the rules is that employees consciously comply with company-specified rules, b. Following the way the company determined work. Responsible is the ability to carry out the duties and regulations within the company. Complete the work at the time specified by the employee should be responsible for his work by completing the job at exactly the time specified company (Hasibuan, 2005).

\section{Employee Performance}

Employee performance is the achievement or work result both quality and quantity achieved human resources in carrying out its duties in accordance with the responsibilities given to him. Quality of work is the ability of employees to show the quality of work in terms of thoroughness and neatness. Quantity of work is the ability of employees in completing a number of daily tasks. Knowledge of work is understanding of all levels of work and matters relating to it. Initiative is related to the power of thought and creativity in the form of ideas for an organizational purpose. Each initiative should receive the attention or positive response from the boss. If the employer always tackles the employee's initiative then the organization will lose energy or the impetus to move forward. Creativeness is the authenticity of the ideas raised and the actions to resolve the problems that arise (Artana, 2002). 


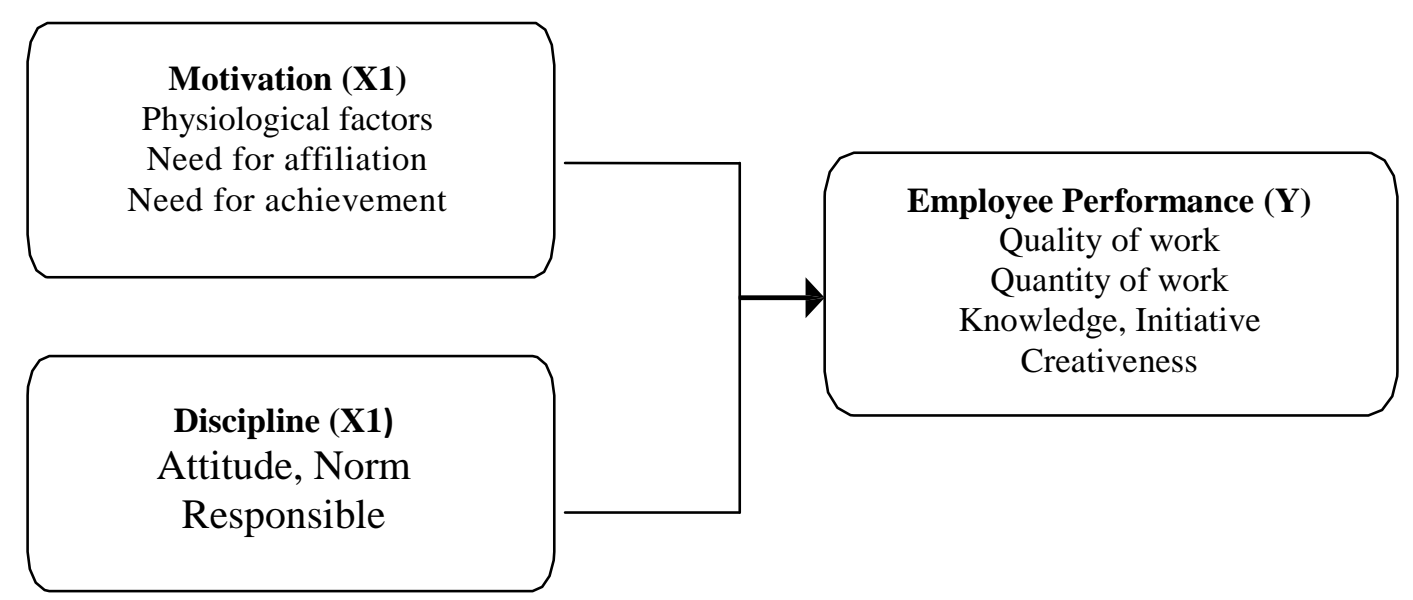

FIG I. FRAMEWORKS

\section{METHODS}

\section{A. Data}

\section{Population}

Population is a generalization area consisting of objects / subjects that have certain qualities and characteristics set by the researchers to be studied and then drawn conclusions (Sugiyono, 2004). Population in research on UPT workers. Marketing is the division of PMB Trisakti School of Tourism, amounting to 40 workers.

\section{Sample}

The sample is part of the number and characteristics possessed by that population. When the population is large, and researchers are not likely to study everything in the population, for example due to limited funds, energy and time, the researchers can use samples taken from that population (Sugiyono, 2004). Irawan (1999) suggested that some experts say if the population $\leq 100$ taken all as a sample, but if the population $\geq 100$ taken at least $25-30 \%$. So, the sample in this study is all workers at PMB Trisakti School of Tourism. The sample of primary data questionnaire is taken 100\% (instrument percent) that is 40 workers in PMB Trisakti School of Tourism.

\section{B. Method}

Method of taking data used in this research is by using questioner or questionnaire. Questionnaire method according to Indriantoro (2002) is the collection of research data on certain conditions may not require the presence of researchers. Researcher's questions and respondents' answers can be put forward in writing through a questionnaire. The purpose of making the questionnaire is to obtain relevant information from the research respondents. The questionnaire in this study consisted of questions derived from each of the research instruments.

The questionnaire is distinguished into a closed questionnaire, i.e the correspondent is only given the opportunity to choose the answers that have been provided in accordance with his opinion and open questionnaire that respondents are given the opportunity to answer in accordance with his opinion freely. The statements in the questionnaire were accompanied by an answer using a scale of 1 to 6 to obtain interval data.

In response to the questionnaire question, we used measurements with Likert scale (Sekaran, 2006). The Likert scale is designed to examine how strongly the subject agrees or disagrees with the question on a 6-point scale with the following arrangement. The answers available on the scale are scored or scored as follows; for category Strongly Disagree (STS) score or value 1 (one), Disagree (TS) score or value 2 (two), Less Agree (KS) score or value 3 (three), Simply Agree (CS) score or value 4 ( four), Agree (S) score or value 5 (five), Strongly Agree (SS) score or value 6 (six).

\begin{tabular}{|c|c|c|c|c|c|}
\hline 1 & 2 & 3 & 4 & 5 & 6 \\
\hline STS & TS & KS CS S SS
\end{tabular}


The following interpretation criteria scores are based on the interval (This is the interval of its distance from the low $0 \%$ to the $100 \%$ high):
- $0 \%-16.99 \%$
- $17 \%-33.99 \%$ $=$ Strongly Disagree
- $34 \%-50.99 \%$
$=$ Not Agree
- $51 \%-65.99 \%$
$=$ Less Agree
- $68 \%-84.99 \%$
$=$ Simply Agree
- $85 \%-100 \%$
$=$ Agree
$=$ Strongly Agree

C. Table and Figure

TABLE II DIMENSION OF VARIABLE

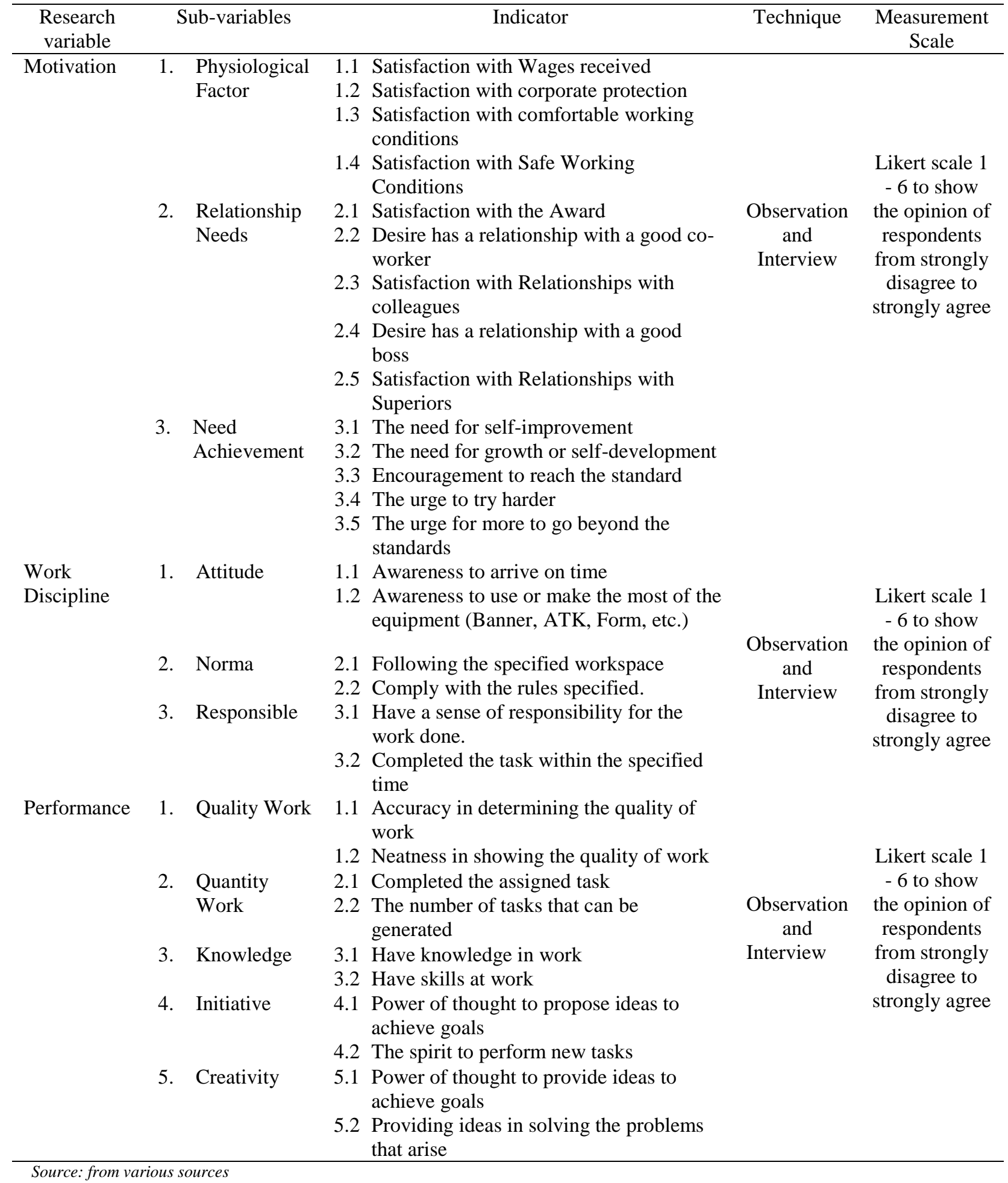




\section{Linear Regression Analysis}

According Sugiyono (2010) parametric statistics are used to analyze interval and ratio data. The regression analysis model used in this research is linear regression analysis. To test the effect of independent variable to one dependent variable is expressed by the following formula;

The formula $Y=\alpha+\beta 1 X 1+\beta 2 X 2$

$\mathrm{Y}=$ dependent variable, i.e employee performance

$\alpha=$ Constants

$\beta 1=$ variable regression coefficient 1

$\beta 2=$ regression coefficient of variable 2

$\mathrm{X} 1=$ independent variable 1

$\mathrm{X} 2$ = independent variable 2

\section{RESULTS AND DISCUSSION}

\section{A. Data of Respondents}

Respondents are workers who work in PMB Trisakti High School working more or less the last year, the period 2016 - 2017.

TABLE III. DESCRIPTION OF RESPONDENT'S AGE

\begin{tabular}{ccc}
\hline Age (Years) & Total & Precentage (\%) \\
\hline $16-20$ y.o & 19 & $47.5 \%$ \\
$21-24$ y,o & 19 & $47.5 \%$ \\
$>25$ y.o & 2 & $5 \%$ \\
Total & 40 & $100 \%$ \\
\hline
\end{tabular}

Sources; Primary Data, 2017

It can be seen in the table above that for the highest is for 16 - 20 Years and 21 - 24 Years as many as 19 people $(47.5 \%)$ and the lowest in> 25 years as many as 2 people $(5 \%)$ only. So it can be concluded that workers at the research site has had a number of fairly positive qualities formed by both superior over the age of 25 years. Carried and applied to the job, experience, consideration, strong work ethic, commitment to quality, and low level of retirement due to age are closely related to the level of maturity and maturity of a person in thinking.

\section{TABLE IV. DESCRIPTION OF RESPONDENT'S GENDER}

\begin{tabular}{ccc}
\hline Gender & Frequency & Percentage (\%) \\
\hline Female & 24 & $60 \%$ \\
Male & 16 & $40 \%$ \\
Total & 40 & $100 \%$ \\
\hline
\end{tabular}

Sources: Sources; Primary Data, 2017

According Sugiyono (2010) valid is to show the degree of accuracy between the actual data occurs on the object with data that can be collected by researchers. Testing the validity is done aims to test the research instrument for the research instrument can provide results in accordance with the objectives by calculating and comparing the correlation between the score of items with the total score. The diagnostic measure is a reliability coefficient that assesses the consistency of the entire scale, with Alpha Cronbach being the most widely used in measurement. These statistics give an indication of the average correlation between all items that make up the scale. Pallant (2001) states that; "Value range from 0 to 1 , with higher values indicating frater reliability". Generally agreed the lower limit for Alpha Cronbach is 0.7. One issue in assessing Alpha Cronbach is a positive relationship with the number of items in the scale. Due to an increase in the number of items, even with the same degree of Intercorelation will increase the value of reliability. 


\section{B. Statement of results}

According Sugiyono (2010) parametric statistics are used to analyze interval and ratio data. The regression analysis model used in this research is linear regression analysis. To test the effect of independent variables on one dependent variable.

\section{TABLE V. MODEL SUMMARY VARIABLE MOTIVATION (X1) AND VARIABLE PERFORMANCE (Y)}

\begin{tabular}{lcrrr}
\hline Model & $\mathrm{R}$ & R Square & Adjusted R Square & Std. Error of the Estimate \\
\hline 1 & $.802^{\mathrm{a}}$ & .642 & .633 & .32965 \\
\hline Sources; & Primary Data, 2017 & &
\end{tabular}

The result of analysis obtained based on summary table model in table 4:19 is the partial correlation between the motivation with the performance with product moment correlation by Pearson obtained $r$ value of 0.802 . The value of this correlation is said to be good enough because $>0.600$ and has a positive value so it can be said pattern of relationship between motivation and performance is unidirectional. Herzberg says that salaries and relatively small allowances affect a person's work performance, but the organization's overall policy affects employee motives for achievement or not.

\section{TABLE VI. MODEL SUMMARY VARIABLE WORK DISCIPLINE (X2) AND VARIABLE PERFORMANCE $(\mathrm{Y})$}

\begin{tabular}{lrrrr}
\hline Model & R & R Square & $\begin{array}{c}\text { Adjusted R } \\
\text { Square }\end{array}$ & $\begin{array}{c}\text { Std. Error of the } \\
\text { Estimate }\end{array}$ \\
\hline 1 & $.847^{\mathrm{a}}$ & .718 & .710 & .29302 \\
\hline
\end{tabular}

Sources; Primary Data, 2017

The result of the analysis obtained based on the summary table model in Table 4:22 is the partial correlation value between the work discipline with the performance with product moment correlation by Pearson obtained $r$ value of 0.847 . The value of this correlation is said to be good because $>0.600$ and has a positive value so it can be said pattern of relationship between work discipline and performance is unidirectional.

TABLE VII. CORRELATION OF VARIABLE MOTIVATION AND VARIABLE WORK DISCIPLINE TO PERFORMANCE VARIABLES

\begin{tabular}{clccc}
\hline \multicolumn{5}{c}{ Correlations } \\
\hline & & Motivation $(\mathrm{X} 1)$ & Discipline $(\mathrm{X} 2)$ & Performance $(\mathrm{Y})$ \\
\hline \multirow{2}{*}{ Pearson } & Motivation $(\mathrm{X} 1)$ & 1 & 0.885 & 0.802 \\
Correlation & Discipline $(\mathrm{X} 2)$ & 0.885 & 1 & 0.847 \\
& Performance $(\mathrm{Y})$ & 0.802 & 0.847 & 1 \\
Sig. (2-tailed) & Motivation $(\mathrm{X} 1)$ &. & 0.000 & 0.000 \\
& Discipline $(\mathrm{X} 2)$ & 0.000 &. & 0.000 \\
& Performance $(\mathrm{Y})$ & 0.000 & 0.000 &. \\
$\mathrm{~N}$ & Motivation $(\mathrm{X} 1)$ & 40 & 40 & 40 \\
& Discipline $(\mathrm{X} 2)$ & 40 & 40 & 40 \\
\hline
\end{tabular}

Sources; Primary Data, 2017

TABLE VIII. COEFFICIENT DOMINANT VARIABLE

\begin{tabular}{|c|c|c|c|c|c|c|}
\hline & \multirow[t]{2}{*}{ Model } & \multicolumn{2}{|c|}{ Unstandardized Coefficients } & $\begin{array}{l}\text { Standardized } \\
\text { Coefficients }\end{array}$ & \multirow[t]{2}{*}{$\mathrm{t}$} & \multirow[t]{2}{*}{ Sig. } \\
\hline & & B & Std. Error & Beta & & \\
\hline \multirow{3}{*}{1} & (Constant) & .386 & .475 & & .813 & .422 \\
\hline & Motivation & .243 & .187 & .239 & 1.298 & .202 \\
\hline & Discipline & .626 & .181 & .636 & 3.458 & .001 \\
\hline
\end{tabular}

Sources; Primary Data, 2017 
Seen in the correlation table then the value that has the closest and significant relationship is the work discipline and then known in the coefficient variable table is more dominant in determining the improvement of performance is the discipline of 0.626 in accordance with the said work discipline should be grown to grow also order and efficiency.

\section{Explanatory text}

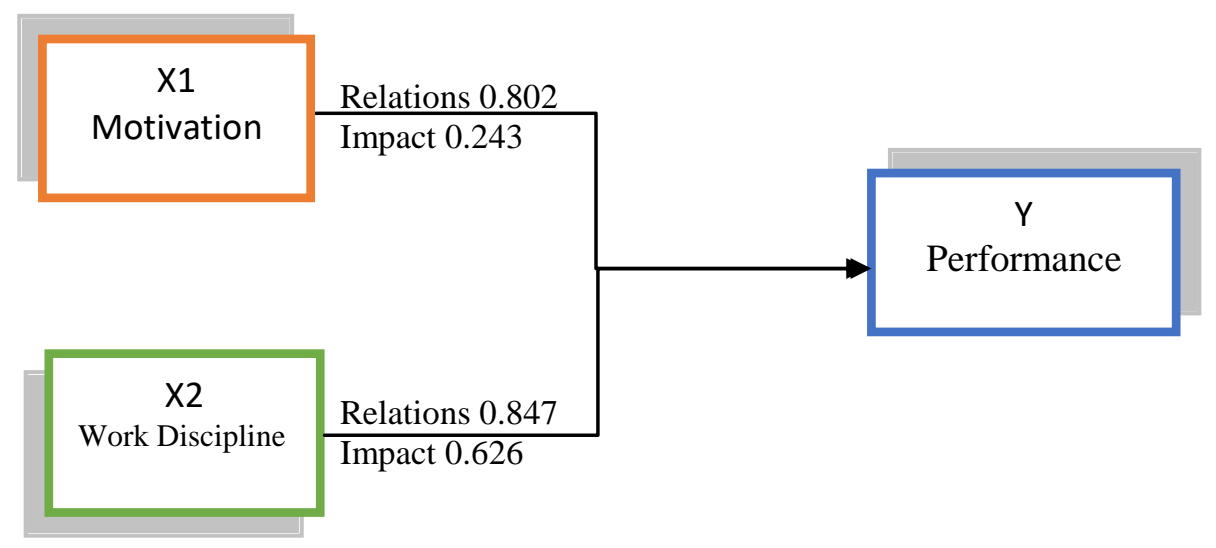

Sources; Resources

\section{FIG II FRAMEWORK RESULT}

From the results of this study states that the motivation has a direct relationship of 0.802 or $80.2 \%$ and an effect of 0.243 . It can be said that the motivation variable in motivation and work discipline has a relationship with the performance of $80.2 \%$ and has the effect of 0.243 . While for work discipline variables have a direct relationship of 0.847 or $84.7 \%$ and an effect of 0.626 . It can be said that the work discipline variable in motivation and work discipline has a performance of $84.7 \%$ and has a dominant influence to performance of 0.626 .

\section{Discussion}

Motivation has a direct relationship with performance and has a positive value of 0.802 , with the coefficient of determination shows the value of 0.642 or equal to $64.2 \%$, it shows that the increase in performance has a positive relationship to motivation. While the hypothesis test for reliability in performance with a significant level of 0.000 smaller than 0.05 states there is a significant effect of motivation on worker performance.

Work discipline has a direct relationship with performance and has a positive value of 0.847 , with the coefficient of determination shows the value of 0.718 or equal to $71.8 \%$, it shows that the improvement of performance has a positive relationship to the discipline of work. While the hypothesis test for reliability in performance with a significant level of 0.000 smaller than 0.05 states there is a significant influence between performances with motivation.

\section{CONCLUSION}

From the results of this study states that the motivation has a direct relationship of 0.802 or $80.2 \%$ and an effect of 0.243 . It can be said that the motivation variable in motivation and work discipline has a relationship with the performance of $80.2 \%$ and has the effect of 0.243 . While for work discipline variables have a direct relationship of 0.847 or $84.7 \%$ and an effect of 0.626 . It can be said that the work discipline variable in motivation and work discipline has a performance of $84.7 \%$ and has a dominant influence to performance of 0.626 .

Implication of this study are based on the results of this study can be said that in improving the motivation can affect the achievement of PMB Trisakti School of Tourism performance. For the physiological factors in the sub variables of motivation, there is an increasing difference in performance when compared to the need for the relationships of PMB workers. This is a factor that improves performance higher than physiological factors and achievement needs in PMB workers. Based on the results of this study can be said that in the work discipline PMB workers have an influence on performance. Workers with high work discipline certainly have better performance than 
workers with moderate and low work discipline. It is expected that the management of PMB can foster work discipline in the workers in various ways, especially in improving attitude factors. Based on the results of this study can be said that the performance in the PMB has a relationship. The existence of interaction between motivation and discipline of work high, medium and low in this study, is expected to increase higher in performance to be able to maintain and can achieve targets that if not met by the PMB workers. It is this initiative factor that in which PMB workers have an impact and has a significant impact on performance.

PMB Trisakti School of Tourism to be able to maintain motivation in the factors of relationship needs, and more to increase motivation in physiological factors of its workers, with one of them increase wage and job protection guarantee to the worker of PMB Trisakti School of Tourism works discipline is good enough, but must be able to maintain the attitude has already been established and upgraded the application in the established norms, by establishing regulations which can be discussed with workers to reach a collective agreement. Performance in PMB Trisakti School of Tourism where the initiative factor is good enough and must be maintained. Where the quality factor of work in accuracy and tidiness in work should be improved even more, by conducting an audit per two weeks or at a time at the end of the month.

\section{REFERENCES}

Artana, I Wayan Arta, 2002, "Pengaruh Kepemimpinan, Kompensasi, dan Lingkungan Kerja terhadap Performance Karyawan Studi Kasus di Maya Ubud Resto dan Spa”, Jurnal Perhotelan dan dan Pariwisata, Vol. 2 No. 1:66.

Basu Swastha dan Irawan, (1999), Manajemen Pemasaran Modern, Edisi 2, Yogyakarta : Liberty

FIMI Dataset Repository, http://fimi.cs.helsinki.fi/data/ Retrieved 09 August, 2011.

Han, J., Kamber, M., and Pei, J., "Data Mining: Concepts and Techniques, $3^{\text {rd }}$ edition," Morgan Kaufmann, 2011.

Hasibuan, Malayu S.P, 2005. Manajemen Sources Daya Manusia. Jakarta: PT Bumi Aksara

J. P. Wilkinson, “Nonlinear resonant circuit devices,” U.S. Patent 3624 12, July 16, 1990.

Leung, C. K-S, Khan Q.I., Li, Z., and Hoque, T., "CanTree: A Canonical-Order Tree for Incremental Frequent-Pattern Mining," Knowledge and Information Systems 11 (3), 287-311 (2007).

Pallant, Julie. (2001). SPSS survival guide: a step-by-step guide to data analysis using SPSS. Victoria: McPherson Printing Group

Pei, J., Han, J., Lu, H., Nishio, S., Tang, S., and Yang, D, "Hmine: Hyper-Structure Mining of Frequent Patterns in Large Databases," In the Proceedings of IEEE International Conference on Data Mining, IEEE Press, 441-448 (2001).

Robbins. Stephen. P., Coulter. Mary. (2012). Management. Eleventh Edition. Jakarta: England

Robbins. Stephen. P., Coulter. Mary. (2012). Management. Eleventh Edition. Jakarta: England

Sugiyono. 2004. Metode Penelitian Bisnis: Penerbit CV. Alfabeta: Bandung

Sugiyono. 2010. Metode Penelitian Kuantitatif Kualitatif \& RND. Bandung: CV.ALFABETA

Tanbeer, S.K., Chowdhury, F.A., Jeong, B.S., Lee, Y-K.,"CP-Tree: A Tree Structure for Single-Pass Frequent Pattern Mining," In T. Washio et al. (Eds.), Lecture Notes in Artificial Intelligence 5012, Springer, 1022-1027. (2008).

Williams, J., "Narrow-band analyzer," Ph.D. dissertation, Department of Electrical Engineering, Harvard University, Cambridge, MA, 1993. 